\title{
Unilateral Statement under International Law: A Vietnamese Position to the Legal Effect of the Diplomatic Note 1958
}

Tran Thang Long*

Owing to the lack of consensus in formal negotiations, unilateral statements do not create legal obligations on states. Thus, a unilateral statement is not considered a source of international law under Article 38 of the Statute of the International Court of Justice. In practice, however, these statements can be legally binding on the states making them and play an important role in the development of international law. The paper aims to examine the characteristics of unilateral declarations and statements in international law and address the Vietnam's position over the legal effects of the Diplomatic Note 1958 with special references to the South China Sea dispute. This paper will analyze the characteristics and significance of unilateral statements in international law, and argue the conditions for legal binding force. Finally, this paper will provide an in-depth clarification on Vietnamese position on the legal effect of the Diplomatic Note 1958.

\section{Keywords}

Unilateral Statement, Diplomatic Note 1958, International Legal Obligations, Erga Omnes, Vietnam

\footnotetext{
* Associate Professor of International Law at Ho Chi Minh City University of Law, Vietnam. B.A./ LL.M. (Ho Chi Minh City U. of Law), Ph.D. (La Trobe U.). ORCID: https://orcid.org/0000-0002-0764-6838. The author may be contacted at: ttlong@hcmulaw.edu.vn/Address: 2-4 Nguyen Tat Thanh Street, District 4, Ho Chi Minh City, Vietnam.

All the website recited from this article were last visited on October 11, 2021.
} 


\section{Introduction}

In international relations, states would often make unilateral statements or declarations. ${ }^{1}$ They are the most common forms of "unilateral acts of state." ${ }^{2}$ It denotes an act "made or entered upon by one party," especially without a reciprocal obligation on part of another or others. 'Unilateral' here refers to a certain course of action or conduct of a single side. It is different from conduct that involves two or more sides-bilateral or multilateral. ${ }^{3}$ A unilateral act of State may be defined as "an expression of will emanating from one State or States, which produces legal effects in conformity with international law."

Many international lawyers discuss "unilateral declarations or statements.", These declarations and statements are of two kinds: (i) those involved in various regulatory processes (conventional, customary, and institutional); and (ii) those that may be able to create, autonomously and independently, legal obligations binding third parties or the international community as a whole. In principle, such unilateral acts are not general international law, but can just create legal obligations on the condition that they contain a clear and unequivocal expression of the will of the state to this effect. These acts may constitute an exception to the traditional conception that legal rules are formed by a process or consensus (pacta sunt servanda) for creating an international obligation.

The term "unilateral acts" covers a wide spectrum of behaviors, but has been often misunderstood for different legal cultures. The UN International Law Commission

1 In this article, the terms "statement" and "declaration" are used interchangeably.

2 A unilateral act is performed or undertaken by or on the part of one side. It is made, enjoyed, shared, and felt, etc., by one party alone. See J. Simpson \& E. Weiner (eds.), The Oxford English Dictionary (2d. ed. 1989).

3 E. Kassoti, Juridical Nature of Unilateral Acts in International Law, FinNish Y.B. InT'L L. 417 (2012-13).

4 Oxford Dictionary of Public International Law, Unilateral Acts of States in International Law, https://opil.ouplaw.com/ view/10.1093/law:epil/9780199231690/law-9780199231690-e1496.

5 F. Jiménez García, Unilateral Acts in International Law-Oxford Bibliographies (2017), https://www. oxfordbibliographies.com/view/document/obo-9780199796953/obo-9780199796953-0116.xml. See also A. Gigante, The Effect of Unilateral State Acts in International Law, 2 N.Y.U.J. InT'L L. \& PoL. 333-62 (1969); A. Rubin, The International Legal Effects of Unilateral Declarations, 1 Am. J. INT'L L. 1-30 (1977); E. Kassoti, The Sound of One Hand Clapping: Unilateral Declarations of Independence in International Law, 2 German L. J. 215-36 (2014); S. Przemyslaw, Unilateral Acts of States in Public International Law 7-33 (2015); E. Kassoti, Unilateral Acts as Juridical Acts, in The Juridical Nature of Unilateral Acts of States in International LaW 78-110 (E. Kassoti ed., 2015); M. Hosein, The Authentication of Countries' Unilateral Acts as a Source in International Law, 2 J. BASIC. APPL. SCI. REs. 2737-744 (2012).

6 García, $i d$.

7 Id.

8 Oxford Dictionary of Public International Law, supra note 4. 
(ILC) adopted the Guiding Principles on Unilateral Declarations of States Capable of Creating Legal Obligations in 2006, which restated the viewpoints in the Nuclear Tests cases, wherein "declarations publicly made and manifesting the will to be bound may have the effect of creating legal obligations" if they were made by "an authority with the power to do so," and such effect would depend on the "declarations' content, ... all the factual circumstances in which they were made, and of the reactions to which they gave rise and are "in clear and specific terms." In this article, the words "statement" and "declaration" are limited that they merely cover the expression of will made by an authorized representative of a state with respect to a particular matter arising under international law. These declarations and statements should directly or indirectly pertain to either a specific state, or a few or large number of states.

The primary purpose of this research is to examine the characteristics of unilateral declarations and statements in international law and address the Vietnam's position over the legal effects of the Diplomatic Note 1958 in relation to the South China Sea dispute. This paper is composed of seven parts including Introduction and Conclusion. Part two will analyze the characteristics of unilateral statements. It is followed by a discussion on the types of unilateral statements. This author will continue to discuss the significance of unilateral statements in international law and argue the conditions for legal binding force of unilateral statements. The final parts of this paper will provide an in-depth clarification on Vietnamese position on the legal effect of the Diplomatic Note 1958.

\section{Characteristics of Unilateral Statement}

Unilateral statements play an important role in international relations as one of the most frequently used tools of state interaction in the sense they express the official position of a state on particular issues in international relations or formulate government policy regarding future intentions. ${ }^{11}$ In this regard, they are legally binding the state itself like a source of international law. A few Vietnamese studies have considered unilateral statements manifestations of state behavior in treaty

9 Princs. 1, 3, 4 \& 7. See U.N. Doc. A/61/10 (May 1-June 9 \& July 3-Aug. 11, 2006), https://legal.un.org/ilc/texts/ instruments/english/commentaries/9_9_2006.pdf.

10 Nuclear Test Case (Austl. v. Fr.), Judgment, 1974 I.C.J. Rep. 253, 43 (Dec. 20); Nuclear Test Case (N.Z. v. Fr.), Judgment, 1974 I.C.J. Rep. 457, ๆ 46 (Dec. 20).

11 C. Goodman, Pacta Sunt Servanda - A Regime for Regulating the Unilateral Acts of States at International Law, 25 AustL. Y.B. INT'L L. 44-5 (2006). 
relations. ${ }^{12}$ Its legal effects and contributions to the development of international law are similar to those of customary international law. ${ }^{13}$ The Ha Noi Law University Textbook defines a unilateral act of a state as a "legal act having international nature in both content and form made by competent state authorities, leading to certain results in international relations."

International law scholars also note that unilateral acts, declarations, and statements may produce legal effects internationally. ${ }^{15}$ According to Urios Moliner, "unilateral acts" (or "unilateral declarations") are "the expression of will formulated by a subject of the international legal order with the intention of producing legal effects at the international level." "Rigaldies defined "unilateral acts of states" as "an expression of will envisaged in public international law as emanating from a single subject of law and resulting in the modification of the legal order." ${ }^{, 17}$ This conception emerges from a single expression of will and formulates norms to apply to subjects of law that "have not participated in the formulation of the act." ${ }^{18}$ Unlike purely diplomatic statements, unilateral statements may lead to the establishment, change, suspension, or termination of the rights and obligations of the claiming state based on international law. Since the Nuclear Tests case, ${ }^{19}$ this issue has become apparent. However, unilateral statements are not official sources of international law under Article 38 of the International Court of Justice (ICJ). Even if unilateral statements may imply the

12 The Giao Trinh Cong Phap Quoc Te [Textbook On Public International Law] of Ho Chi Minh City University of Law published in 2013 considers a "state's unilateral statements" as a basis for customary international law. See also L.E. van Binh, Bao luu va Tuyen bo trong Dieu uoc Quoc te [Reservation and Declarations in International Treaties], 23 VNUJS-EL 151-8 (2007); T. K. N. Nguyen \& O. H. Do, Quyen Bao luu va Mot so Tuyen bo Don phuong cua Quoc gia khi Tham gia Dieu uoc Quoc te [The Right to Reservation and Some Declarations of States when Participating in International Treaties], 8 InDUSTRY \& TRADE MAG. 9 (2017), http://tapchicongthuong.vn/bai-viet/quyen-bao-luu-va-motso-tuyen-bo-don-phuong-cua-quoc-gia-khi-tham-gia-dieu-uoc-quoc-te-27543.htm.

13 See Ho Chi Minh City University of Law Textbook, supra note 12, at 150; Ha Nor Law U., Giao Trinh Luat Quoc Te [TEXTBOOK On InTERnational Law] 28 (17th ed. 2018).

14 Ha Noi Law U., id. at 31.

15 M. Shaw, International Law 114 (5th ed. 2008). See also G. Triggs, International Law: Contemporary Principles and Practices 148 (2d ed. 2011); I. Brownlie, Principles of Public International Law 85 (6th ed. 1990).

16 V. Rodríguez Cedeño, Fifth Report on Unilateral Acts of States (2002), https://legal.un.org/ilc/documentation/english/ a_cn4_525.pdf.

17 Urios Moliner, "Actos unilaterales y derecho internacional público: delimitación de una figura susceptible de un régimen jurídico común”, Castellón, Universitat Jaume I, Mimeographed (Unpublished Ph.D. Thesis, University Jaume I, Spain, April 2001), recited from V. Rodríguez Cedeño, Ninth Report on Unilateral Acts of States (2006), ๆ 92, https://legal. un.org/ilc/documentation/english/a_cn4_569.pdf; Rigaldies, Contribution à l'étude de l'acte juridique unilatéral en droit international public, 15 REVUE JURIDIQUE THÉMIS 417-51 (1980-81); Jacqué, Éléments pour une théorie de l'acte juridique en droit international public, Paris, LGDJ, (1972) at 329, recited from Victor Rodríguez Cedeño, supra note 16 at 99.

18 Id.

19 Nuclear Test Cases (Austl. v. Fr.), Judgment, 1974 I.C.J. Rep. 267 (Dec. 20); Nuclear Test Cases (N.Z. v. Fr.), Judgment, 1974 I.C.J. Rep. 473 (Dec. 20). See also SHAw, supra note 15, at 114; Triggs, supra note 15, at 148; BRowNLIE, supra note 15 , at 85 . 
intention to bind the state making it to other states or the international community as a legal obligation, its legal effects are not strong enough. Although "unilateral statements" are not always valid in international law, in practice, states rely on them. In this regard, the recognition of the legal validity of such statements is evolving as a form of customary international law. ${ }^{20}$ According to the ILC, in specific cases, the unilateral acts of a state, including unilateral statements made by official representatives of states can create legal obligations. ${ }^{21}$ A question may arise if a unilateral statement made and accepted by the states has legal binding force like a treaty.

\section{Types of Unilateral Statement}

\section{A. Declaration of Independence}

A state can declare its independence and sovereignty over its territory without any formal acceptance of the state that had previously dominated or annexed it. The ICJ, in its Advisory Opinion on Kosovo's declaration of independence from Serbia on February 17, 2008 observed that Kosovo's declaration had not violated international law. ${ }^{22}$ In 1998, the Canadian Supreme Court ruled on Quebec's secession, noting that "a state can only secede if it is a victim of colonial rule, oppression, or exploitation, or has no access to the federal government." ${ }^{23}$ Vietnam's Declaration of Independence dated September 2, 1945 is also a good example. ${ }^{24}$ Although the declaration was unilateral, it formally established the legal rights and obligations for the Democratic Republic of Vietnam (DRV) as a full subject of international law.

\section{B. Declaration of State/Government Recognition}

In international law, "recognition" may be defined as "a unilateral declaration of

20 C. Goodman, Pacta Sunt Servanda? A Regime for Regulating the Unilateral Acts of States at International Law, 25 AustL. Y.B. INT'L L. (2006), http://classic.austlii.edu.au/au/journals/AUYrBkIntLaw/2006/3.html.

21 Brownle, supra note 15, at 637-40. See also Rubin, supra note 5, at 1.

22 Accordance with International Law of the Unilateral Declaration of Independence in Respect of Kosovo, Advisory Opinion, I.C.J. Rep. 452 (July 22).

23 Supreme Court of Canada, Reference re Secession of Quebec, SCC-CSC, [1998] 2 S.C.R. 217, 1154 (Aug. 20), https:// scc-csc.lexum.com/scc-csc/scc-csc/en/item/1643/index.do.

24 It states: “... from now on we break off all relations of a colonial character with France; we repeal all the international obligation that France has so far subscribed to on behalf of Vietnam and we abolish all the special rights the French have unlawfully acquired in our Fatherland." See Declaration of Independence of the Democratic Republic of Vietnam, $\mathrm{http} / /$ historymatters.gmu.edu/d/5139. 
will whereby a subject of international law acknowledges the existence of a fact, a situation or a claim and expresses its will to consider them legitimate." is a political as well as legal act of a state to acknowledge another state as an official diplomatic counterpart. State recognition means that one state acknowledges "the [political] entity fulfils the criteria of statehood," while government recognition implies that the regime in question is in effective control of a state." ${ }^{26}$ It is mainly based on political, economic, and defensive motivations. Recognition is often expressed through an official or implied act or declaration that acknowledges the existence of and affirms the relations with the new state (or government) in question. It also aims to present the recognizing state's intention to establish a normal and stable relationship with the new state (or government). ${ }^{27}$ Recognition has often been formulated through diplomatic notes such as Venezuela's Declaration dated May 5, 1992, when it recognized "the Republic of Slovenia as sovereign and independent," and its Declarations dated May 5 and August 14, 1992, when it recognized the Republics of Croatia and Bosnia and Herzegovina, respectively. ${ }^{28}$ Such statements confirm the new state's legal and practical existence and paves the way for the establishment of external relations between the recognizing and recognized states, thereby creating essential premises for the latter to gradually enter into international relations in the future.

\section{Declaration of Commitment}

A Declaration of Commitment turns a unilateral act into a legally binding action. The statement expressed in the Italian Protection Law of 1871 recognized the inviolability and commitment of the Pope's special powers. The Egyptian Government's Statement on the Suez Canal to permit ships to navigate the canal freely, and the French Government's Statement calling for the end of nuclear testing in airspace can be considered declarations of commitment to the international community. This category includes Declarations of War and Neutrality, such as Austria's Declaration of Permanent Neutrality under its Constitution, dated October 26, $1955 .^{29}$ Such

25 Unilateral Acts of States: Sixth report on unilateral acts of States, by Mr. Victor Rodríguez Cedeño, Special Rapporteur, U.N. Doc. A/CN.4/534, at 61, ๆ 48 (May 30, 2003), https://legal.un.org/ilc/documentation/english/a_cn4_534.pdf.

26 P. MalanczuK, Akehurst's Modern Introduction to International Law 82 (7th ed. 1997).

27 Ho Chi Minh City University of Law, supra note 12, at 184.

28 Libro Amarillo de la República de Venezuela correspondiente al año 1992 (Caracas, Ministry for Foreign Affairs 1992), recited from Cedeño, supra note 16, at 95.

29 Constitutional Law on the Neutrality of Austria (Oct. 26, 1955), art. 1. It reads: "(1) For the purpose of the lasting maintenance of her independence externally, and for the purpose of the inviolability of her territory, Austria declares of her own free will her perpetual neutrality. Austria will maintain and defend this with all means at her disposal." 
statements bind the state and make them adhere to the rights and obligations they agreed to comply with.

\section{Declaration to Waive Sovereignty}

While declarations to waive sovereignty are unilateral, they share characteristics with those that aim to waive or exhibit a state's international commitments, such as in the Eastern Greenland case, ${ }^{30}$ where the Ihlen Declaration expressed the recognition of a legal reality (Danish sovereignty over East Greenland) and a commitment (Norway pledged not to interfere in Danish activities on this territory and waived the right to claim sovereignty over the territory). ${ }^{31}$ The Colombian government's statement of recognition of Venezuela's sovereignty over the Los Monjes Islands can be considered a statement of recognition, commitment, or waiver, wherein the Colombian government stated that it would neither contest Venezuela's sovereignty over the aforementioned archipelago, nor make any claim on the exercise of Venezuelan sovereignty over it. ${ }^{32}$ Or, it is the commitment to conduct an act or non-specific act, such as Egypt's claim to sovereignty over the Suez Canal and the freedom of navigation on this international canal. ${ }^{33}$ Such a statement expresses the independent will of the state in which that state voluntarily gives up its rights and obligations to a particular territory or to restrict or abandon certain areas under its sovereign control. A waiver of rights is a unilateral declaration of a legal nature. Statements expressing the security commitments of a nuclear-armed state in which that declaring state emphasizes its intention not to use nuclear weapons against a state without such weapons can be classified under this category. The Declaration of the US State Department announcing the US's waiver of its claim to sovereignty over 25 Pacific Islands is also an example of this category.

\section{E. Declaration of Objection}

This is a declaration by which a state exhibits its intent not to recognize a situation, claim, attitude, or conduct of another actor in international relations. This statement

30 U.N. Doc. A/CN.4/534 (2003). See also Legal Status of Eastern Greenland (Den. v. Nor.), 1933 P.C.I.J. (ser. A/B) No. 53 (Apr. 5).

31 Legal Status of Eastern Greenland, $i d$. $\mid 58$.

32 Affaire des Frontières Colombo-Vénézuéliennes (1922) 1 UNRIAA 22. https://legal.un.org/riaa/cases/vol_I/223-298.pdf.

33 Declaration on the Suez Canal and the Arrangements of Its Operation, U.N. Doc. A/3576 (Apr. 24, 1957), https:// digitallibrary.un.org/record/574836/files/A_3576_S_3818-EN.pdf.

34 UN Special Rapporteur, Eighth Report on Unilateral Acts of States, by Mr. Víctor Rodríguez Cedeño, U.N. Doc. A/ CN.4/557 (2004), at 222-3. 
must be expressed explicitly by a competent authority. A statement of objection, whereby a state expresses its intention to oppose or not recognize certain acts of a target state at times is considered to establish a form of renunciation, such as in the Preah Vihear Temple case. ${ }^{36}$ The ICJ noted that Thailand had no objection to the map in this case, ${ }^{37}$ which made it mandatory for Thailand to comply with the border line so created. A statement of objection has the effect of refusing to impose a legal obligation. Such an objection prevents the inference that a situation which already took place earlier would become unchangeable later on estoppel.

\section{F. Declaration of Maritime Sovereignty}

A typical example of a state's unilateral behavior for maritime sovereignty was the Truman Declaration, which was made on September 28, 1945, regarding the US's right to mineral resources of the seabed and the seabed itself. This Declaration became the ground for Latin American countries to announce the expansion of their continental shelves, such as Mexico in 1946 and Panama in 1947, which was followed by a series of unilateral claims made by Peru, Chile, and Ecuador over territorial seas that extended up to 200 nautical miles, followed by multilateral statements by Latin American states in the joint statement of Santiago (1952) and Montevideo (1970) on the same issue. These unilateral claims of maritime sovereignty contributed to creating the concept of the Exclusive Economic Zones before the United Nations Convention on the Law of the Sea 1982 (UNCLOS). Unlike optional or selective statements in international treaties, ${ }^{41}$ such declarations appear unilaterally, and shall be inferred and made based on the perspectives and arguments of the claimant state in order to demonstrate their

35 Kassoti, supra note 3, at 452-3. See also Armed Activities on the Territory of the Congo Case, New Application 2002, Judgment, 2006 I.C.J. Rep. 6, 9 - 46-7 (Feb. 3).

36 Preah Vihear Temple Case (Cambodia v. Thail.), Judgement, 1962 I.C.J. Rep. 6, at 23 (June 15).

37 Preah Vihear Temple Case (Cambodia v. Thail.), Judgement, 1961 I.C.J. Rep. 27 (May 26). See also A. Ovchar, Estoppel in the Jurisprudence of the ICJ A principle promoting stability threatens to undermine it, 21 BOND L. REv. 12-3 (2009).

38 D. Bowett, Estoppel before International Tribunals and Its Relation to Acquiescence, 33 BRITISH Y.B. InT'L L. 197-8 (1957).

39 Proclamation 2667-Policy of the United States With Respect to the Natural Resources of the Subsoil and Sea Bed of the Continental Shelf, 3 CFR, 1943-1948 Comp., at 437, https://www.gc.noaa.gov/documents/gcil_proc_2667.pdf.

40 Mexico proclaimed its jurisdiction, protection and control over the continental shelf bordering its territory by the President's Declaration dated October 29, 1945. See R. Young, Recent Developments with Respect to the Continental Shelf, 42 Am. J. Int'L L. 851 (1948); H. Morris, The Continental Shelf-an International Dilemma, 1 Osgoode Hall L. J. 39 (1958); UN Division of Ocean Affairs and the Law of the Sea, The United Nations Convention on the Law of the Sea (A historical perspective) 1998, https://www.un.org/depts/los/convention_agreements/convention_historical_ perspective.htm.

$41 \quad$ ICCPR art. 41. 
interests. On the "first" and "no objection" basis, it creates a situation where legal rights and obligations of the state concerned are established.

\section{G. Statements to Accept the ICJ Jurisdiction}

Some statements may accept the jurisdiction of the ICJ in advance, in accordance with Article 36 of the Statute. ${ }^{42}$ States have the full right to express their will by making such unilateral declarations at any time, referring to the essential conditions necessary to accept the jurisdiction of the Court. ${ }^{43}$ According to the Statute, non-member states of the UN can still become a party to the Court if they declare the acceptance of the ICJ's decisions either in general, or in particular disputes. ${ }^{44}$ In addition, states may issue unilateral declarations of prior acceptance of the jurisdiction of an international arbitration tribunal, which will authorize the tribunal to exercise jurisdiction if a dispute occurs.

\section{Significance of Unilateral Statement}

\section{A. The Expression of a State's Position on International Relations}

A unilateral statement is an expression of a state's position on international relations. It represents the state's assessment of a fact or situation and expresses its perspectives on how to deal with such problems or matters. These statements are often political and legal in nature, reflecting the general foreign policy of the state in question. In the Eastern Greenland case, the ICJ maintained that unilateral statements may be used as evidence of a particular view espoused by a state. In response to the opinion of the ICJ in the Kosovo case, for example, Spain expressed opposition, stating that Kosovo's declaration of independence was not consistent with international law and violated the Federal Republic of Yugoslavia (Today's Serbia)'s right to sovereignty and

42 Currently, 66 states have accepted the optional clause of Article 36 of the ICJ Statute.

43 I.C.J. Statute art. 36(2) \& (4).

44 For example, Switzerland announced its acceptance of the Court's jurisdiction in 1948 before joining the UN on September 10, 2002. The Republic of San Marino declared its acceptance of the ICJ's jurisdiction in 1954, before joining the UN on March 2, 1992.

45 UNCLOS annex VII, art. 287 ( $§ 3 \& 5)$.

46 Maritime Delimitation in the Area between Greenland and Jan Mayen (Den. v. Nor.), Judgment, 1993 I.C.J. Rep. 38 ฯ 51 (June 14). 
territorial integrity. ${ }^{47}$ This statement made it clear that Spain, based on its concerns around the risk of secession from its territories, did not recognize the legal entities that had separated from the former Yugoslavia.

\section{B. The Creation of Legally Binding Obligations}

Unilateral legal acts of states express the intentions of these states in international relations with legal consequences for both the state itself and the international community at large. ${ }^{48}$ First, other states can rely on such statements and demand that the state making such statements fulfill its obligations later. They have the right to require the state to respect its statements.

Second, when the state is willing to accept the binding nature of the contents of its statement, this intention makes the statement a legal commitment. As such, the state making it is obliged to comply with the contents of its statement under the principle of pacta sunt servanda. In such cases, the statement enters into force without any acceptance or response from any other state. In the Nuclear Tests cases, the ICJ emphasized: "Declarations made by way of unilateral acts, concerning legal or factual situations, may have the effect of creating legal obligations." "J1 Judging by the French government's text and its contextual background with seriousness, these statements have clear and specific goals. Therefore, it created a legal obligation that forced France to fulfill its commitments. The ICJ maintained that even if not all unilateral statements are binding on states, such claims would be legally valid. In this regard, the Court held that a unilateral statement was also considered to be legally binding as international obligations to take actions consistent with this statement. ${ }^{52}$ Thus, states are entitled to require that the obligation thus created be respected by these statements.

\section{A Circumstances for Estoppel}

Although a unilateral statement may create an international obligation with legal binding force, it will not immediately create estoppel. Whether or not unilateral statements may be one of the factors leading to estoppel depends on the facts and

47 Reply of the Kingdom of Spain to questions posed by Judges Koroma, Bennouna and Cançado Trindade at the close of the oral proceedings (Dec. 2009), https://www.icj-cij.org/public/files/case-related/141/17902.pdf.

48 D. Degan, Sources of International Law 259 (1997).

49 Preah Vihear Temple Case, supra note 37, \48; U.N. Doc. A/61/10 (2006).

50 A. Fellmeth \& M. Horwitz, Guide to Latin in International Law 212 (2009).

51 Nuclear Tests Cases, supra note 10, at 267, $₫ 43$.

52 Id. at 267, 46.

53 Id at $268, \uparrow 46$. 
circumstances involved. The principle of estoppel was applied by the ICJ in many border and territory dispute cases which dealt with the statements made by authorized representatives of the disputing parties. The main purpose of estoppel is to prevent a state from benefiting from its inconsistent attitudes and thus causing damage to another state. ${ }^{54}$ A statement will only give rise to estoppel if it is expressed clearly and specifically. Therefore, the text of the statement should be considered first as the foremost factor, along with a consideration of the context in and circumstances under which the statement was made. ${ }^{55}$ In the Eastern Greenland case, the PCIJ adjudicated that the unilateral statements were binding as they were made in the context of the larger negotiations in progress, and the contents of these statements were clear, voluntary, and trusted by the parties.

Estoppel emerges when a state makes a generic unilateral promise or a specific one pertaining to a certain issue. In the Nuclear Tests case, the ICJ noted that France was bound by its unilateral declaration, so that it would end nuclear testing in the airspace. $^{57}$ It also noted that this statement expressed the French government's intention to be bound by the declaration, and was thus legally valid. ${ }^{58}$ The ICJ's rulings implies that unilateral commitments may create an estoppel. In the Eastern Greenland case, the PCIJ cited the Norwegian Foreign Minister's Statement, made on behalf of the Norwegian Government on July 22, 1919, which clearly stated: "I told the Danish Minister today that the Norwegian Government would not make any difficulty in the settlement of this question [Greenland]." The Court held that, although the [Norwegian] Ministry of Foreign Affairs did not intend to "transfer and have a definite recognition of Danish sovereignty over Greenland," the Danish was able to rely on its commitment that Norway would not preclude Danish plans for Greenland, and hence, such a commitment by the Minister of Foreign Affairs would bind Norway. ${ }^{60}$ In the Nuclear Tests case, France's official message expressing its intention to stop conducting nuclear weapons tests in the airspace was delivered to Australia, New Zealand, and the entire world.

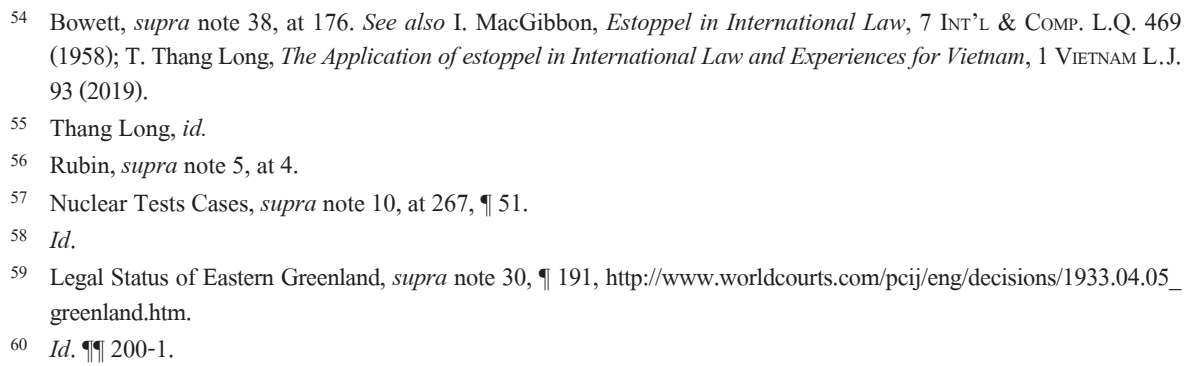




\section{The Creation of Customary International Law}

Customary international law can emerge from unilateral acts and statements of states. Such acts and statements serve as a template for behavioral and repetitive behavior, which meets one of the criteria for the formation of an international custom. $^{61}$ Although a unilateral statement may be considered a source of customary international law (under the ambit of "state practice"), a number of essential criteria must be fulfilled including opinio juris. ${ }^{62}$ The statement also reaffirmed the non-normative nature of a unilateral statement. For example, when a state make a unilateral statement that establishes its national sovereignty over particular territory in the airspace or underground, there is an automatic assumption that aerial and underground borders have been established and are planned through the establishment and development of land and maritime boundaries. ${ }^{63}$ The Truman Declaration established the US's sovereignty and jurisdiction over "the seabed and subsoil, located in international waters but continues with the coast of the United States was of the United States." ${ }^{, 64}$ Then, Latin American states like Argentina (October 11, 1946), Mexico (October 29, 1946), Panama (August 1, 1947), Costa Rica (July 27, 1948), and El Salvador (September 14, 1950) announced the expansion of their continental shelves. This became a customary rule in international maritime law and was officially formulated as Article 2 of the Geneva Convention on the Continental Shelf of $1958 .^{65}$ Similarly, unilateral claims of maritime sovereignty in the 1970s contributed to the formation of the EEZ as a customary rule. The ICJ stated that: "the Truman Declaration, ... soon became a starting point for the actual law of the matter, and the dominant position on which it was based ... became more dominant than other rules, and reflected in Article 2 of the 1958 Geneva Convention on the Continental Shelf., ${ }^{66}$

61 Ho Chi Minh City University of Law, supra note 12, at 148-9 \& 150.

62 Opinio juris connotes an element in the formation of international custom, expressed in Article 38(1)(b) of the ICJ Statute as "a general practice accepted as law." See C. PARRY \& J. Grant, Encyclopaedic Dictionary of International LAW 440 (2d ed. 2004).

63 This assumption is based on the maxim - "Cuius est solum eius est usque ad coelum (et ad inferos)," which means: "To whomsoever it belongs, it is his all the way to the heavens (and all the way to hell)." See A. Fellmeth \& M. Horwitz, Guide to Latin in InTERnational Law 16 \& 69 (2009).

64 Proclamation 2667, supra note 39.

65 UN Division of Ocean Affairs and the Law of the Sea, supra note 40. See D. Rothwell \& T. STEPHEns, The InTERNATIONAL LAW OF THE SEA 101 (2010).

66 North Sea Continental Shelf (F.R.G. v. Den.; F.R.G. v. Neth.), Judgement, 1969 I.C.J. Rep. ๆ 47 (Feb. 27). 


\section{Conditions for Legal Binding Force of Unilateral Statement}

\section{A. The statement must be made by the state's competent authorities.}

The PCIJ clarified the issue in its precedents, such as the Eastern Greenland case. ${ }^{67}$ The ICJ has repeatedly held that a representation is: (i) authorized only if it is made by an organ competent to bind the State; and (ii) deemed unconditional unless it is made in the course of negotiations or is subject to express conditions.

In the Congo case, ${ }^{69}$ the ICJ referred to the customary rules of international treaty law, which was defined later under Article 7(2) of the Vienna Convention on the Law of Treaties 1969 (VCLT), that the Heads of State, Heads of Government and Ministers for Foreign Affairs, are considered to represent their States for the sake of performing all acts relating to the conclusion of a treaty. This has been expressed in a number of cases such as Eastern Greenland, ${ }^{70}$ Nuclear Tests (Austl. v. Fr.), and Genocide, and the Arrest Warrant.

In the Nuclear Tests case, the ICJ held that, according to the official function of the President, his statements and exchanges expressed in writing and verbal form were undoubtedly all valid vis-à-vis the international relations of France. ${ }^{74}$ Other statements of the French government including that of the Minister of Defense dated on October 11, 1974 thus formed part of state action which were committed, regardless of how they were deliberated.

There are three conditions on whether these unilateral statements should comply with domestic law. First, the statement must be made by a qualified person. Second, the consideration of the statement's legal validity in international law must be grounded in international treaty law, which has confirmed the rule. ${ }^{75}$ Third, it

67 Legal Status of Eastern Greenland, supra note 30, ๆ 58.

68 Id. $\uparrow \uparrow$ 88-90. See also A. Ovchar, Estoppel in the Jurisprudence of the ICJ A principle promoting stability threatens to undermine it, 21 Bond L. Rev. 16-17 (2009); Thang Long, supra note 54.

69 Armed Activities on the Territory of the Congo, supra note 35, ๆ 46, https://www.icj-cij.org/public/files/caserelated/126/126-20060203-JUD-01-00-EN.pdf.

70 Legal Status of Eastern Greenland, supra note 30, ๆ 289.

71 Nuclear Test Cases, supra note 10, at 267, $₫ 49$.

72 The Application of the Convention on the Prevention and Punishment of the Crime of Genocide (Bosn. \& Herz. v. Sern. \& Montenegro), Judgement, 1996 I.C.J. Rep. 595, ๆ 44 (July 11).

73 The Arrest Warrant of April 112000 (Congo v. Belg.), Judgement, 2002 I.C.J. Rep. 3, ๆ 51 (Feb. 14).

74 Nuclear Tests Cases, supra note 10, at 267, 49.

75 VCLT art. 46 (1). 
can be asserted by subsequent practice of the state in question. ${ }^{76}$ In the statement made by the King of Jordan regarding the territory of the West Bank, ${ }^{77}$ although it was claimed by the Head of State of Jordan, the statement was later confirmed by Jordan's subsequent acts for legal binding force. As the Colombian Foreign Minister's statement on Venezuelan sovereignty over the Los Monjes Islands was not objected to by the competent authorities of Colombia, it finally became binding on the Colombian side.

\section{B. A clear, open statement and the contents must convey the consent to be bound.}

In the Nuclear Tests case, the ICJ stressed that a unilateral statement can create a legally binding obligation on the state that made the statement only if it was presented expressly and particularly. ${ }^{79}$ This test was applied in the Congo case. ${ }^{80}$ The ICJ's judgment in the Nuclear Tests case emphasized that: "When States make statements by which their freedom of action is to be limited, a restrictive interpretation is called for." "In explaining such obligations, the textual content of the statement should be considered first, followed by due consideration for the context in and circumstances under which it was made.

If a statement has the nature of explanation clarifying the binding intention of a state, its interpretation should be analogously in accordance with Article 31(1) of VCLT. Here, the content of the statement shall be considered first, because it clearly represents the intention of the party making the statement. In the Frontier Dispute case, the ICJ also stated that "in order to assess the intentions of the author of a unilateral act, account must be taken of al1 the factual circumstances in which the act occurred." ${ }^{83}$ In addition, the application by analogy of Article 31(2) of VCLT can be taken into account.

77 The statement made by the King of Jordan on 31 July 1988 waiving Jordan's claims to the West Bank territories, 27 I.L.M. 6 (Nov. 1988), - 1637, recited from U.N. Doc. A/CN.4/557, supra note 34, at 126.

78 Nuclear Tests Cases, supra note 10, at 267, 44.

79 Id. at 269 , 43; 472, ๆ $51 ; \& 474$, ๆ 53.

80 Armed Activities on the Territory of the Congo, supra note $35, \uparrow \uparrow 50 \& 52$.

81 Nuclear Tests Cases, supra note 10, at 267, 44.

82 U.N. Doc. A/61/10 (2006).

83 Frontier Dispute (Burk. Faso v. Mali), 1986 I.C.J. 554, 40 (Dec. 22); Armed Activities on the Territory of the Congo, supra note 35, ๆ 49; and Nuclear Tests, supra note 10, at 269, ๆ $51 \& 474$, ๆ 53.

84 The ICJ held: "to assess the intentions of the author of a unilateral act, account must be taken of all the circumstances in which the act occurred." See Frontier Dispute, supra note 83, 140. 
The statements made by the French government in 1974, the Egyptian Declaration of April 24, 1957 on the Suez Canal, the Jordanian Declaration on its claim to the West Bank, and the Ihlen Declaration as well as the unilateral diplomatic note to the Venezuelan authorities, are all typical examples of clear and open statements expressing consent to be bound. The ILC, on its opinion in the Nuclear Tests case, noted that binding intent is important in establishing the legality of the statement. ${ }^{85}$ In the Nuclear Test case, the ICJ further held:

when it is the intention of the State making the declaration that it should become bound according to its terms, that intention confers on the declaration the character of a legal undertaking, the State being thenceforth legally required to follow a course of conduct consistent with the declaration..." and "an undertaking of this kind, if given publicly, and with an intent to be bound, even though not made within the context of international negotiations, is binding.

\section{It should be accepted by the states concerned.}

Under international law, obligations cannot be assigned by one state to another without the consent of the latter, as an obligation must be established by mutual consent among the relevant parties. ${ }^{87}$ This principle may also apply to unilateral statements. It means a state cannot assign obligations to any other state through a statement, unless such other state has explicitly accepted obligations arising out of those statements. In such cases, the states concerned have agreed to be bound by the unilateral statement expressing their consent. For example, the Truman Declaration was implicitly accepted by other states. ${ }^{88}$ This Declaration was affirmed by the ICJ as an example of a legal doctrine arising out of a specific source. ${ }^{89}$ Other states responded to the Truman Declaration with similar claims and statements and then the content of this Declaration was included under Article 2 of the Geneva Convention on the Continental Shelf of 1958.

\section{It can be either verbal or written in form.}

Through the ICJ's precedents, it has been generally accepted that the form of a unilateral statement shall not prejudice its effects or legal validity. In the Preah

85 U.N. Doc. A/61/10 (2006), at 370.

86 Nuclear Tests Cases, supra note 10, at 267, 44.

87 VCLT art. 34.

88 Young, supra note 40, at 851. See also Rothwell \& STEPHENS, supra note 65, at 101.

89 North Sea Continental Shelf, supra note 66, at 53, 100. 
Vihear Temple case, ${ }^{90}$ the ICJ held: "where ... as is generally the case in international law, which places the principal emphasis on the intentions of the parties, the law prescribes no particular form, parties are free to choose what form they please provided their intention clearly results from it." In the Nuclear Tests case, the ICJ adjudicated that the mode of statement-either verbal or written-does not make a difference when statements are made under particular circumstances that can create commitments under international law, unless they are required to be expressed in writing. ${ }^{92}$ Thus, the matter of form is not decisive.

State practice shows many ways to making unilateral statements. For example, the French statements on ending nuclear testing in airspace were made in the form of a diplomatic note-a letter from the French President to concerned states, press conferences, and speeches delivered before the UN General Assembly. ${ }^{93}$ All these statements were considered acceptable so long as they conveyed the same message. In the Nuclear Tests case, the ICJ did not focus on a single statement made by the French government alone, but rather considered the separate statements as a whole. Therefore, regardless of the form, statements should be considered to have created a national commitment to their intentions and the circumstances under which they were made. ${ }^{94}$ Other examples show that while written unilateral statements are predominant, states can also make statements verbally, such as the abovementioned example of Jordan through a speech, and the Ihlen statement which was personal. ${ }^{95}$

\section{E. It should be given to a specific state, to some countries, or the international community at large.}

Statements are often made within the scope of bilateral relations between two states. Accordingly, the statements made by one state are directed to another as the sole recipient. Noticeable examples are the Colombia's diplomatic note to Venezuela, the Cuban statement regarding the supply of vaccines to Uruguay, the Russian Federation's objections to Turkmenistan and Azerbaijan, and the Ihlen Declaration. Some statements initially involve a limited number of states, while others have

90 Preah Vihear Temple Case, supra note 37, at 31, https://www.icj-cij.org/public/files/case-related/45/045-19610526JUD-01-00-EN.pdf.

$91 \quad$ Id.

92 Nuclear Tests, supra note 10, at 473, 948.

93 U.N. Doc. A/CN.4/557 (2004), 9 ศ 71-72.

94 Nuclear Tests, supra note 10 , at 269 , $49 \& 474$, 51.

95 Id. $₫ 45$.

96 U.N. A/CN.4/557 (2004), ๆๆ 85 \& 99. 
been directed the entire international community at large. Therefore, the Egyptian declaration of the Suez Canal was not only addressed to the countries that were party to the Constantinople Convention and the members of the Association of States that utilized the Suez Canal, but to the entire international community. ${ }^{97}$ Similarly, the Truman Declaration and the French statements concerning the termination of nuclear tests had the nature of erga omnes. ${ }^{98}$ The statement dated July 31, 1988 renouncing Jordan's claim to the West Bank territory was sent simultaneously to the international community, to Israel, and to the Palestine Liberation Organization (PLO).

\section{F. It is not contrary to the peremptory obligations under international law.}

A unilateral statement in contrast to a jus cogens ${ }^{99}$ shall be ipso facto null and void under Article 53 of VCLT. Most ILC members agree that there are no obstacles to applying this rule to a unilateral declaration. ${ }^{100}$ In the Congo case, the ICJ did not rule out the possibility that a unilateral statement made by Rwanda could be invalid as it conflicted with a jus cogens norm.

\section{The Vietnamese Position to the Diplomatic Note 1958}

When meeting the criteria and conditions under international law, a state's unilateral statements can create legal binding force for the state making such statements like treaty obligations. A state's unilateral statements have certain roles in developing international law as they can generate legal binding norms under some condition which, to some extent, can serve as sources of customary law. It is finally forming general international law on the lines of estoppel. Considering the nature of these statements and analyzing their legal effects for the state making such statements in the international arena are thus significant, especially in the resolution of disputes around sovereignty and territory as follows. First, unilateral statements shall play a role in

97 Declaration on the Suez Canal and the Arrangements of Its Operation.

98 Erga Onmes may be defined as "obligations in whose fulfillment all states have a legal interest because their subject matter is important to the international community as a whole." See OXford Dictionary of Law 179 (5th ed. 2002).

99 Jus cogens may be defined as a rule or principle in international law that is so fundamental that it binds all states and does not allow any exceptions. See id. at 274.

100 U.N. GAOR 54th Sess. Supp. No. 10, U.N. Doc. A/54/10, at 332 (May 3 \& July 23, 1999).

101 Armed Activities on the Territory of the Congo, supra note 35, $\mid 69$. 
confirming legal basis for the territorial sovereignty of the claimant state. In this case, the statements have often been considered as legal arguments by the international tribunal. For example, the consistent assertion and evidence of Vietnam for its sovereignty have confirmed and consolidated its position in the disputes of the South China Sea. These will be also invoked before a tribunal dealing with this matter in the future. Second, unilateral statements shall play an important role in refuting views and arguments of the disputing party regarding the possibility of creating estoppel. A mere unilateral statement itself is not sufficient to be an estoppel. An estoppel must satisfy three conditions: (1) The expression must be clear and unambiguous; (2) The expression must be voluntary, unconditional, and authoritative; and (3) There is a good faith reliance upon the representation of one party by the other, either to the detriment of the relying party or to the advantage of the party making the representation. ${ }^{102}$ Thus, unless these core elements are met, estoppel cannot be formed and such unilateral statements cannot be seen as creating legal obligations in the international arena.

In case of the sovereignty disputes over the Paracel (Hoang Sa) and Spratly (Truong Sa) archipelagos, the Chinese government always cited historical evidence and diverse legal bases to counter Vietnam's claim of sovereignty over both entities centering on the letter from the late Prime Minister Pham Van Dong to the General Secretary of the State Council of China Zhou Enlai in 1958 (hereinafter Diplomatic Note 1958). ${ }^{103}$ In this context, estoppel could not be established for Vietnam. Therefore, Vietnam need to create more stable legal ground for its arguments in order to reject China's interpretation of Diplomatic Note 1958. Vietnam's stance is firmly based on the argument that China's alleged statements failed to create legal obligations because they do not fulfill the following conditions.

(1) It is impossible to make any claims regarding sovereignty over the archipelagos in the South China Sea by the Democratic Republic of Vietnam (DRV), which led to its failure to qualify the first criterion mentioned above. ${ }^{104}$

(2) There is no consent or intent to be bound by the party making the statements in question. As analyzed above, a mere promise is very difficult to legally bind the state that made this promise, unless it clearly shows the intent of the given state. There were no clear and specific expressions of consent or intent to be bound

102 For details, see Bowett, supra note 38, at 202; Thang Long, supra note 54.

103 This issue was mentioned by China in its White Paper 1980 and most recently in two Public Notes at the UN. See U.N. Doc. A/68/907 (2014) \& U.N. Doc. A/68/956 (2014). In particular, the Public Note (A/68/907) has also attached in its Annex the full text of this Official Letter.

104 The competence criterion to make unilateral statements that subsequently lead to an estoppel was also confirmed in a number of cases tried by the ICJ and other international tribunals, such as Congo and Eastern Greenland. 
that could be inferred from the acts of DRV both at the time and thereafter. In explaining the content of such obligations, the textual content of the statement should be considered first, followed by the context in and circumstances under which it was made. ${ }^{105}$

(3) There is no clear and unambiguous expression on part of the state making the statements that culminate in the assumption of an estoppel. The message conveyed by the Government of the DRV aimed to acknowledge and endorse the Declaration of the Government of the People's Republic of China dated September 4,1958 . The statement of the Government of the PRC regarding the territorial sea on September 4, 1958 consists of 4 points. In particular, point 1 of the original Chinese text translated into English reads: "The breadth of the territorial sea of the People's Republic of China shall be 12 nautical miles. This provision applies to all territories of the People's Republic of China, including the Chinese mainland and its coastal islands, as well as Taiwan (separated from the mainland and its coastal islands by the high sea) and its surrounding islands, the Penghu Islands and the Dongsha Islands, the Xisha Islands, the Zhongsha Islands, the Nansha Islands, and all other islands belonging to China." ${ }^{, 106}$ On September 14, the late Vietnam's Prime Minister Pham Van Dong issued a Diplomatic Note addressed to the Prime Minister Zhou Enlai, expressing Vietnam's respect for China's Declaration. The Note was publicized on September 22 in Vietnamese People's newspaper. ${ }^{107}$ The contents of this document consists of two clear points: (1) Vietnam noticed to the PRC that the Government of DRV had noted and supported the September 4, 1958 Declaration by the PRC, regarding the territorial waters of China; and (2) The Government of DRV would respect this decision and would direct the proper government agencies to absolutely respect the 12 nautical miles' territorial sea of China in all dealings with the PRC on the sea. This means that the Vietnamese side acknowledged China's desire to extend its waters through its unilateral declaration, and indicated that it would agree with this aspiration. The next paragraph may imply that in the good relationship between both countries at the time, the Vietnamese side would respect China's determination of 12 nautical miles as its territorial waters. There is nothing that leads to the assumption that Vietnam had renounced its sovereignty over the Paracel and Spratly archipelagos.

(4) There is no good faith reliance on the representation of one party (Vietnam) by

105 Frontier Dispute (Burk. Faso v. Mali), supra note 83, 9 - 39-40; Armed Activities on the Territory of the Congo Case, supra note 35, ๆ 49; Nuclear Tests, supra note 10, at 269, 51 and at 474-5, 53.

106 US Department of State, 43 Limits in the Seas: Straight Baselines People's Republic of China (July 1, 1972), https://2009-2017.state.gov/documents/organization/58832.pdf.

107 Vu Thanh Ca \& Le Minh Phuong, The 1958 Diplomatic Note of Prime Minister Pham Van Dong and Vietnam's sovereignty over the Hoang Sa and Truong Sa Archipelagos (Oct. 26, 2016) Ly LuAN ChINH Tri, [Political Theory], http://lyluanchinhtri.vn/home/en/index.php/figure-and-events/item/379-the-1958-diplomaticnote-of-prime-ministerpham-van-dong-and-vietnam $\% \mathrm{E} 2 \% 80 \% 99 \mathrm{~s}$-sovereignty-over-thehoang-sa-and-truong-sa-archipelagos.html. 
another (China) either to the detriment of such a relying party or the advantage of the party making the representation. In order to apply the abovementioned core factors constituting an estoppel to the statement of the DRV, as derived from Note 1958, there was a lack of condition with respect to damage to the subject with this trust or, on the contrary, leading to the benefit of the expressive side mentioned above. In 1956, 1958, and 1965, China did not present an original or changed stance in response to the DRV's proclamation. It could not prove that China suffered any damage based on those statements. The DRV did not benefit from its statements, either. The Pham Van Dong statement was entirely political because of the friendship between Vietnam and China, and had no intention to refer to sovereignty, the key factor that may have led the Chinese side to gain confidence in Vietnam's position over the Paracel and Spratly archipelagos. The statement made by the Government of the DRV in 1965 had the same effect. The driving force of that statement was the urgency and sense of danger that prevailed in Vietnam at the time. These were political and not legal statements. Therefore, China must be aware that in the context of the Vietnamese statement, it cannot use the basis for the "reliance" in asserting China's sovereignty or the abandonment of Vietnam's sovereignty over the two archipelagos. ${ }^{108}$

(5) The Diplomatic Note 1958 must be interpreted in is contextual background and purpose. It should follow basic rules of interpreting international treaties, in which the terms of the treaty must be interpreted in their context and must be considered in a whole. ${ }^{109}$ Therefore, it is necessary to trace back to historical background to understand the situation at that time.

First, it was the tension leading to the Declaration of the Government of the PRC on the territorial sea on September 4, 1958. In May 1950, the US sent the 7th Fleet to enter the Taiwan Strait with the aim to guard the island, which was under the Kuomintang's government after 1949, despite China's intense condemnation. It was followed by series of military attacks in implementing the Prime Minister Zhou Enlai to "liberate Taiwan," 110 leading to a tug-of-war. The PRC's declaration was to set a 12 nautical mile territorial sea breadth from China's mainland, including Taiwan. In this context, the need to claim China's 12-nautical-mile territorial sea was reasonable and thus, need for allies' support was understandable.

Second, the context that introduced the four UN Conventions on the Law of the Sea in 1958 should be taken into consideration when China was not a UN member. The PRC's Declaration was to affirm its demands on territorial waters and surrounding areas and express Chinese views on territorial claims. In the

108 Thang Long, supra note 54.

109 VCLT art. 31(2) \& (3).

110 See "April 19, 1955 Main Speech by Premier Zhou Enlai, Head of the Delegation of the People's Republic of China, Distributed at the Plenary Session of the Asian-African Conference," The Wilson Center Digital Archive, https:// digitalarchive.wilsoncenter.org/document/121623.pdf?v=e1cd06384e2e67bdff11f809ead78849. 
outset of the 1950s, there was a pressure on the PRC related to the 12 nautical miles' breadth of its territorial waters in response to the US argument on its military activities in this region and to escalating threats from the US and to invalidate the US naval activities in this region.

Third, it must be seen that the relationship between the two countries in this period was very special. At this time, the DRV and PRC were keeping "close alliance." Since 1956, the DRV in the North sought for the supports of the international community for the national reunification. The international proletarian movement at this period had much affection and support for the North of Vietnam. China was one of the Socialist governments that actively supported the DRV. For Vietnam, supports from the Soviet Union and China were also served for the demand to oppose the US and the ROV. In response to the tug-of-war, The Note 1958 was only intended to support China against the US siege policy in the Taiwanese Strait. Such a spiritual activity did not contain any of Vietnam's abandonment of sovereignty over the Paracel and Spratly archipelagos. ${ }^{111}$

Regarding the Vietnam's sovereignty over the Paracel and Spratly Islands, Vietnam's unilateral claims on its lawful sovereignty shall serve as important arguments and must be fully exploited. Vietnam's statements have been made constantly and firmly since 1951. However, it is arguable that these unilateral statements would express the national position on this question to the international arena which has legal binding force. When a state makes a statement to accept its binding nature, it is legally committed to such expression and obliged to comply with it. Because the DRV is the lawfully succeeded state entity of both the Republic of Vietnam (ROV) and the Socialist Republic of Vietnam (SRV), the statements of all these Vietnamese parties after 1951 represent the Vietnam's sovereign views.

Vietnam should take into account the Declaration of the Prime Minister of the Bao Dai Government, Tran Van Huu at the 1951 San Francisco Peace Treaty before representatives of 51 member states of the UN. He firmly stated: “... we affirm our right to the Spratly and Paracel Islands, which have always belonged to Vietnam..." None of the 51 member states protested the confirmation of Vietnam's sovereignty over these archipelagoes by the Vietnamese Delegation. ${ }^{113}$ The speech of the ROV's delegate delivered at the Second Session of the Third UN Conference on the Law

111 In this context, the 1958 Diplomatic Note of the late Prime Minister Pham Van Dong was suitable to the specific circumstances and relationships between the DRV and PRC at that time. The Note was only a good gesture about friendship and support for China when the US brought the 7th fleet to the Taiwan Strait.

112 Q. T. Nguyen, Hoang SA - Truong Sa 155 (1988). See also Viet Nam's Sovereignty over Hoang Sa and Truong Sa Archipelagoes (Part 3), EAST-SEA.DE, July 14, 2019, http://east-sea.de/en/2019/07/14/english-viet-nams-sovereigntyover-hoang-sa-and-truong-sa-archipelagoes-part-3.

113 T. H. Do, Vietnam and the South China Sea: Politics, Security and Legality 43 (2017). 
of the Sea in Caracas in 1974 is also valuable to reaffirm its entitlement over these two archipelagos. ${ }^{114}$ They represent Vietnam's position with legal binding effect on Vietnam and the states in question.

As part of the Geneva Accords of 1954, Vietnam was temporarily divided into two zones. ${ }^{115}$ The territory from the 17th parallel to the South, including the two archipelagos was set under the control of the State of Vietnam and then succeeded by the ROV, ${ }^{116}$ which was one of the two political entities that correspondingly administered the northern and southern parts of Vietnam. From 1954 to 1976, the ROV peacefully, continuously, and effectively governed the two archipelagos as prescribed under international law ${ }^{117}$ The ROV subsequently issued many legal documents confirming its administration of the archipelagos.

The official statements of the Vietnamese government made after the country's reunification in 1975 served as important legal evidence of the consolidation and confirmation of the continuation of sovereignty, and Vietnam's consistent views asserting its sovereignty over these two archipelagos. These may include, inter alia, the Declaration of the Government of SRV on Vietnam's Territorial Sea, Contiguous Zone, EEZ, and Continental Shelf dated May 12, 1977; the Declaration on the Vietnamese Baseline dated November 12, 1982; the affirmation of the Pacacels and Spratlys as part of Vietnamese territory when Vietnam ratified the UNCLOS on June 23, 1994; and acts in protest against China's conduct by the Vietnamese Foreign Ministry from 1975 to the present. Both the governments in South Vietnam (ROV and PRG) took strong actions against China's seizure of the Paracel. Right after the naval battle on January 19, 1974, the ROV Ministry of Foreign Affairs issued a statement against China's invasion. As soon as the ROV collapsed, the PRG army took over the Spratly Islands

114 Proclamation by the Government of the Republic of Vietnam dated February 14, 1974 stressed: "The Hoang Sa (Paracel) and Truong Sa (Spratly) archipelagoes are an indivisible part of the territory of the Republic of Vietnam. The Government and People of the Republic of Vietnam shall not yield to force and renounce all or part of their sovereignty over those archipelagoes." See Republic of Vietnam Ministry of Foreign Affairs, White Paper on the Hoang Sa (Paracel) and Truong Sa (Spratly) Islands (1975), https://daisukybiendong.files.wordpress.com/2015/05/white-paperon-the-hoang-sa-and-truong-sa-islands-1975-dskbd.pdf. For Vietnamese version on this link, see Hai chien Hoang Sa: Tuyen cao ngay 14.2.1974 cua Chinh phu Viet Nam Cong Hoa [Hoang Sa Battle: Proclamation of the Government of Republic of Vietnam on 14/2.1974], Thanh Nien Online, https://thanhnien.vn/hai-chien-hoang-sa-tuyen-cao-ngay-142-1974-cua-chinh-phu-viet-nam-cong-hoa-post5657.html.

115 Geneva Accords, arts. 1 \& 14. See The Two Vietnams (1954-65), BRITANNICA EnCYClOPEDIA, https://www.britannica. com/place/Vietnam/The-two-Vietnams-1954-65.

116 Geneva Agreements on the Cessation of Hostilities in Viet-Nam (July 20, 1954), https://peacemaker.un.org/sites/ peacemaker.un.org/files/KH-LA-VN_540720_GenevaAgreements.pdf.

$117 \mathrm{Vu}$ Thanh Ca \& Le Minh Phuong, supra note 107.

118 N. B. Dien, Regarding the letter of the late Prime Minister Pham Van Dong, 14 September 1958 and the issue of sovereignty over the two islands Paracels and Spratlys of Vietnam, 27 J. SCI. VIETnAm NAT'L U. 243 (2011). 
and handed over it to the Government of the DRV in the reunification process in 1976.

\section{Conclusion}

In this article, the author has confirmed that unilateral statement is the expression of a state's position on special subject matter in international relations. It can legally bind on that state with regard to some key requirements based on estoppel. The clarification of Vietnam's position on the pledge of the Diplomatic Note 1958 is thus important to oppose China's arguments on the use of the Note.

China has always argued that Vietnam had acknowledged China's sovereignty by citing Diplomatic Note $1958^{119}$ and through the subsequent actions of the government of Vietnam. Here, China contends that an estoppel was established based on a unilateral statement from DRV, so that Vietnam must not take actions contrary to the previous acknowledgement by DRV. ${ }^{120}$ However, Vietnam confirms that China has misrepresented the Diplomatic Note 1958. Vietnam's argument is based on the important conditions of the estoppel principle as mentioned above. ${ }^{121}$

First, the Diplomatic Note 1958 is a unilateral statement. The question is whether such a statement is qualified to produce a legally binding obligation for the state making it, and thus, whether it gives rise to an estoppel or not. Under international law, a mere promise hardly binds a state making such a promise, unless it clearly shows the intent of the given state. The ICJ practice shows that to determine the "intent" factor, the Court must consider all facts surrounding the statement, and check whether it has been stated, and if so, in what context and under what conditions or circumstances. ${ }^{122}$ In the Nuclear Tests case, France declared that it would stop the nuclear testing. The ICJ ruled that because France wanted to be bound by its promise,

119 Supra note 103.

120 Letter dated 9 June 2014 from the Chargé d'affaires a.i. of the Permanent Mission of China to the United Nations addressed to the Secretary-General. See U.N. Doc. A/68/907 (2014), ๆ 5.8, https://undocs.org/a/68/907. The Note (A/68/907) also stated: "prior to 1974, no Vietnamese Government had ever challenged the sovereignty of China over the Xisha Islands. Viet Nam had officially recognized the Xisha Islands as part of China's territory since ancient times." The Press Release of the Ministry of Foreign Affairs of the People's Republic of China noted: "But now the Vietnamese government goes back on its word by making territorial claims over China's Xisha Islands. That is a gross violation of the principles of international law, including the principle of estoppel, and the basic norms governing international relations." See PRC Ministry of Foreign Affairs, The Operation of the HYSY 981 Drilling Rig: Vietnam's Provocation and China's Position (2014/06/08), https:/www.fmprc.gov.cn/mfa_eng/zxxx_662805/t1163264.shtml.

121 Supra note 97.

122 Nuclear Test Cases (Austl. v. Fr.), supra note 10. ๆ 51. 
it was considered appropriately bound. ${ }^{123}$ Without this, the Court may conclude that the state making the statement does not want to be bound by it. This was reaffirmed in the Congo case.

Second, whether Diplomatic Note 1958 created a legally binding obligation for Vietnam and whether it gave rise to effects as an estoppel can be contested by the lack of: (i) damage to the party (China) relying on the expression; and (ii) benefits to the party making the expression. In 1956, 1958 and 1965, China neither presented an original or changed stance in response to the proclamation of DRV, nor proved any damage from those statements. Actually, DRV did not benefit from its statements, either. $^{125}$ The statement of the late Prime Minister Pham Van Dong was entirely 'political' because of the friendship between Vietnam and China. It was made without any intention to refer to sovereignty, the key factor that might lead to the Chinese side's misunderstanding about Vietnam's renouncement of its sovereignty over the Paracel and Spratly archipelagos.

Meanwhile, the 1965 Statement made by the DRV had the same effect, because it was driven by the urgency and sense of danger by the US involvement in Vietnam. This was not legal but political statements. Therefore, in the context of the Vietnamese statement, China cannot argue for the "reliance" as a criterion in order to claim China's sovereignty over the two archipelagos.

The Diplomatic Note 1958 did not mention the territorial sovereignty issues over the Spratly and Paracel archipelagos, so that it has no relevance to both archipelagos. ${ }^{126}$ Vietnam did not express any intent to be legally bound by this unilateral statement. The Note 1958 was merely a diplomatic declaration and lacked the necessary factors to constitute a legally binding obligation for Vietnam in the international arena. Both the "reliance" and "intent" factor should be the key issues in this dispute.

Received: August 1, 2021

Modified: October 1, 2021

Accepted: November 1, 2021

123 Id.

124 Armed Activities on the Territory of the Congo, supra note 35, $\uparrow$ ๆ $50 \& 52$.

125 N.D.b. Nhan dan, Công thu 1958 nhì tù khía cạnh luật pháp quốc tế [The Note of 1958 viewed from international law perspective], DAI BIEU NHAN DAN, June 15, 2014, http://daibieunhandan.vn/default.aspx?tabid=76\&NewsId=318273.

126 Thang Long, supra note 54, at 90-116. 